\title{
Iron Pyrite thin films grown through a one-step annealing of iron oxide using sulfur sources, tert -butyl disulfide and $\mathrm{H}_{2} \mathrm{~S}$
}

Siva P Adusumilli1, 2, Jeremiah M Dederick4, In-Tae Bae3, Sean M Garner5, Anju Sharma3, Charles R Westgate ${ }^{1,2}$, and Tara P Dhakal ${ }^{1,2 *}$

${ }^{1}$ Department of Electrical and Computer Engineering, Binghamton University, Binghamton, NY 13902 ${ }^{2}$ Center for Autonomous Solar Power (CASP), Binghamton University, Binghamton, NY 13902 ${ }^{3}$ Small Scale Systems and Integration Packaging Center (S3IP), Binghamton University, Binghamton, NY 13902

${ }^{4}$ Department of Physics, Applied Physics and Astronomy, Binghamton University, Binghamton, NY 13902

${ }^{5}$ Corning Incorporated, Corning, NY, 14831

Keywords: earth abundant, photovoltaics, Corning ${ }^{\circledR}$ EAGLE $^{\circledR} \mathrm{XG}^{\circledR}$, hydrogen sulfide, tert butyl di sulfide, sodium free glass.

*Corresponding author email: Tara P Dhakal (tdhakal@binghamton.edu)

\section{Abstract}

In this work, we report synthesis of pyrite thin films using tert-butyl disulfide (TBDS) and hydrogen sulfide $\left(\mathrm{H}_{2} \mathrm{~S}\right)$ in one-step atmospheric pressure sulfurization of iron oxide films at $400{ }^{\circ} \mathrm{C}$ on a soda-lime glass, molybdenum coated soda-lime glass and sodium free glass substrates. The iron pyrite thin films grown using TBDS did not require the presence of sodium to form the pyrite phase, whereas $\mathrm{H}_{2} \mathrm{~S}$ grown pyrite thin films did. It was observed that the pyrite formation and thus the sulfur diffusion into the oxide film was slower in TBDS compared to $\mathrm{H}_{2} \mathrm{~S}$. The synthesized films were characterized for their surface morphology and phase identification using scanning electron microscopy, tunneling electron microscopy (TEM), X-ray diffraction (XRD) and X-ray photoemission spectroscopy (XPS) measurements. The S:Fe atomic ratio as well as their chemical bonding states were monitored to obtain 
and maintain a stoichiometric 2:1 ratio through the entire film thickness as a function of the sulfurization time by performing an XPS depth profile. Transmittance measurements confirmed the pyrite phase with an optical bandgap of $1.15 \mathrm{eV}$. The TEM electron-beam diffraction spots were used to verify the impurity phases observed in XRD patterns. Hall Effect measurements showed p-type carriers for the pyrite films.

\section{Introduction}

Earth abundant materials have great potential in producing low cost and high efficiency solar cells [1]. Iron disulfide a.k.a. pyrite $\left(\mathrm{FeS}_{2}\right)$ is one such earthabundant semiconductor that exhibits useful photovoltaic behavior with a direct bandgap of $0.95 \mathrm{eV}$, an optical absorption coefficient of the order of $10^{5} \mathrm{~cm}^{-1}$ [2] and long minority carrier diffusion lengths [3]. In spite of these advantages, the best efficiency observed is $2.8 \%$ using a photochemical cell with an open circuit voltage of $187 \mathrm{mV}$ [4]. This value of the open circuit voltage is well below the theoretical prediction of $500 \mathrm{mV}$ [5]. This modest performance is usually attributed to sulfur deficiency and the resulting bulk deep donor states [6,7], high density of thermodynamically unstable surface states $[8,9]$, and the presence of trace amounts of orthorhombic marcasite and hexagonal troilite phases which have very small bandgaps of $0.34 \mathrm{eV}$ and $0.04 \mathrm{eV}$ respectively [2]. More investigation is needed for

the synthesis of a quality pyrite material with regards to its purity, stoichiometry, crystallinity and grain size for the solar cell applications. 
Since the 1980s, various research groups have proposed and synthesized iron pyrite thin films using a variety of experimental techniques which include sputtering [10], spray pyrolysis [11-13], chemical vapor transport [5], metalorganic chemical vapor deposition [14,15], direct chemical vapor deposition [16], electrodeposition [17], nanocrystal formation [9,18-21], hydrothermal methods $[2,22]$, evaporation $[23,24]$. Some of the sulfur precursors/sources used for pyrite are di-tert butyl di sulfide (TBDS) [25-27], hydrogen disulfide $\left(\mathrm{H}_{2} \mathrm{~S}\right)[14,28,29]$ and elemental sulfur(S) [3,30]. Iron sources used are $\mathrm{Fe}[30,31], \mathrm{Fe}_{\mathrm{x}} \mathrm{O}_{\mathrm{y}}[3,9,32]$, iron pentacarbonyl $\left(\mathrm{Fe}(\mathrm{CO})_{5}\right)[25,27,33]$, and iron acetylacetonate $\left(\mathrm{Fe}(\mathrm{acac})_{3}\right)[18,34,35]$. Compound semiconductor pyrite was formed by cobalt doping for n-type pyrite [15]. Regarding sulfur precursors, single or combination of sulfur precursors $[18,35,36]$ are used.

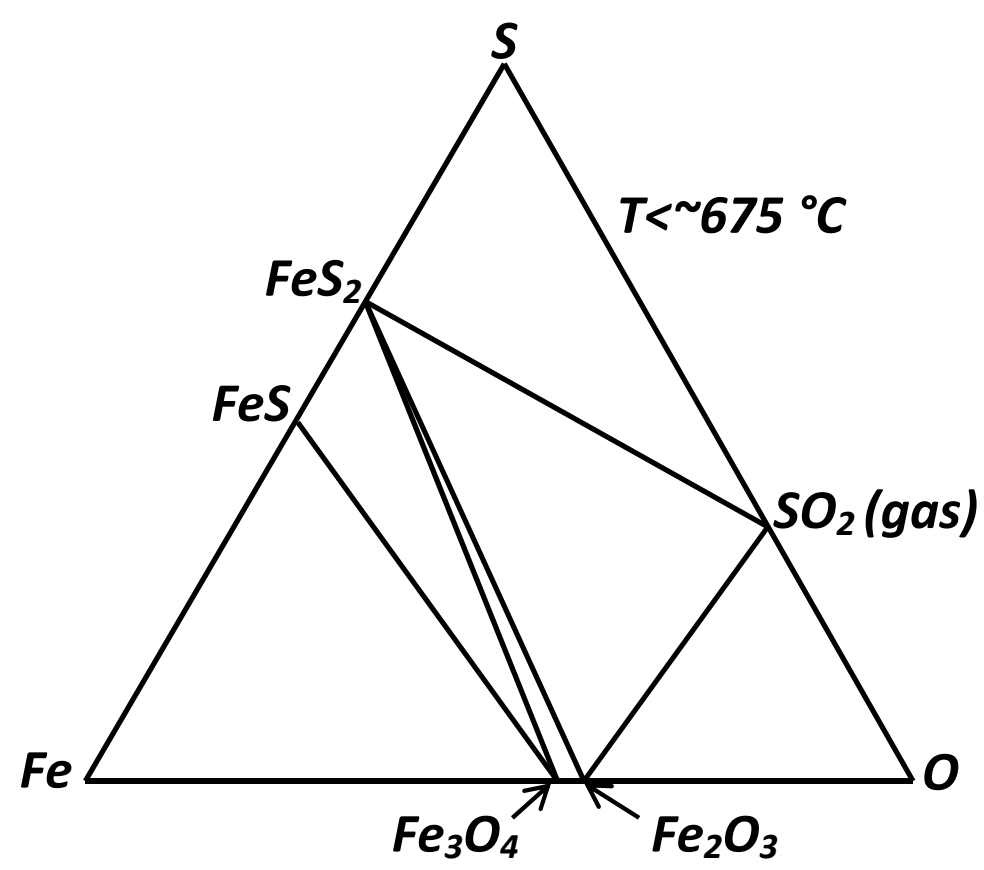

Figure 1: Gibbs free energy phase diagram of Fe-S-O [reproduced with permission from ref. 37]. 
In this work $\mathrm{Fe}_{2} \mathrm{O}_{3}$ was chosen the iron source and TBDS and $\mathrm{H}_{2} \mathrm{~S}$ as the sulfur source. The choice of $\mathrm{Fe}_{2} \mathrm{O}_{3}$ is preferred because the formation of the pyrite without going through the intermediate phase such as FeS as depicted in Fig.1. in the Fe-O-S Gibbs free energy phase diagram $[4,37]$. When only Fe is used, the pyrite formation has to go through the monosulfide to get into disulfide region. The impetus of this work is to synthesize phase pure and stoichiometric pyrite films for application as a photovoltaic absorber.

\section{$1.1 \quad$ Experimental Details}

\subsubsection{Iron oxide film deposition}

Prior to iron oxide $\left(\mathrm{Fe}_{2} \mathrm{O}_{3}\right)$ film growth, the glass substrates were cleaned with soapy water followed by ultra-sonication in dilute $\mathrm{HCl}$ (25 \% in DI water), acetone and ethanol in succession. Then the substrates were rinsed in DI water and dried using the standard clean room grade dry nitrogen. A $600 \mathrm{~nm}$ thick Mo film was then sputtered onto the glass substrate using a target with $99.95 \%$ purity purchased from Kurt. J. Lesker Co. The sputtered molybdenum (Mo) had a sheet resistance of about $5 \mathrm{ohm} / \mathrm{sq}$. For iron oxide film, a $\mathrm{Fe}_{2} \mathrm{O}_{3}$ sputtering target of $99.9 \%$ purity (from Kurt J. Lesker) was used. Thin films of $\mathrm{Fe}_{2} \mathrm{O}_{3}$ of about $300 \mathrm{~nm}$ thickness were sputtered at room temperature on bare as well as Mo-coated glass substrates, allowing us to observe the effect of Mo acting as a blocking layer for Na leaching. The sputter-grown films were confirmed as $\mathrm{Fe}_{2} \mathrm{O}_{3}$ by X-ray photoemission spectroscopy (XPS) and X-ray diffraction (XRD) measurements.

Two types of glasses were used; soda-lime glass from Cardinal Glass Inc. and 
sodium-free Corning ${ }^{\circledR}$ EAGLE XG ${ }^{\circledR}$ Glass [38]. This allowed us to study the effect of Sodium (Na) in pyrite phase formation. The iron oxide films were sulfurized in TBDS and $\mathrm{H}_{2} \mathrm{~S}$ environments using a one-zone quartz tube furnace. Prior to the sulfurization of the $\mathrm{Fe}_{2} \mathrm{O}_{3}$ films, the quartz tube was baked for $2 \mathrm{hrs}$. at $400{ }^{\circ} \mathrm{C}$ and then naturally cooled to room temperature to outgas any chamber contamination. The flow of nitrogen $\left(\mathrm{N}_{2}\right)$ gas was controlled through mass flow controllers (MFC) as shown in Fig. 2. In case of TBDS, the $\mathrm{N}_{2}$ gas bubbled through the precursor via MFC1 to achieve an appreciable amount of TBDS vapor, which then combined with an additional $\mathrm{N}_{2}$ flow through MFC-2 before entering the quartz tube. The annealing temperature was kept at $400{ }^{\circ} \mathrm{C}$, while the time was varied from $6 \mathrm{hrs}$. to 4 days. The annealing was performed in Argon (Ar) gas flow as well, but the results were the same as those for $\mathrm{N}_{2}$. After annealing, the precursor $\mathrm{Fe}_{2} \mathrm{O}_{3}$ film converted into pyrite $\left(\mathrm{FeS}_{2}\right)$ phase.

The setup for $\mathrm{H}_{2} \mathrm{~S}$ sulfurization was similar to the TBDS as shown in Fig. 2. In this case, $\mathrm{H}_{2} \mathrm{~S}$ and $\mathrm{N}_{2}$ gases were sent through mass flow controllers, MFC-3 and MFC-4 respectively. The temperature of the annealing was same as that of TBDS case. 


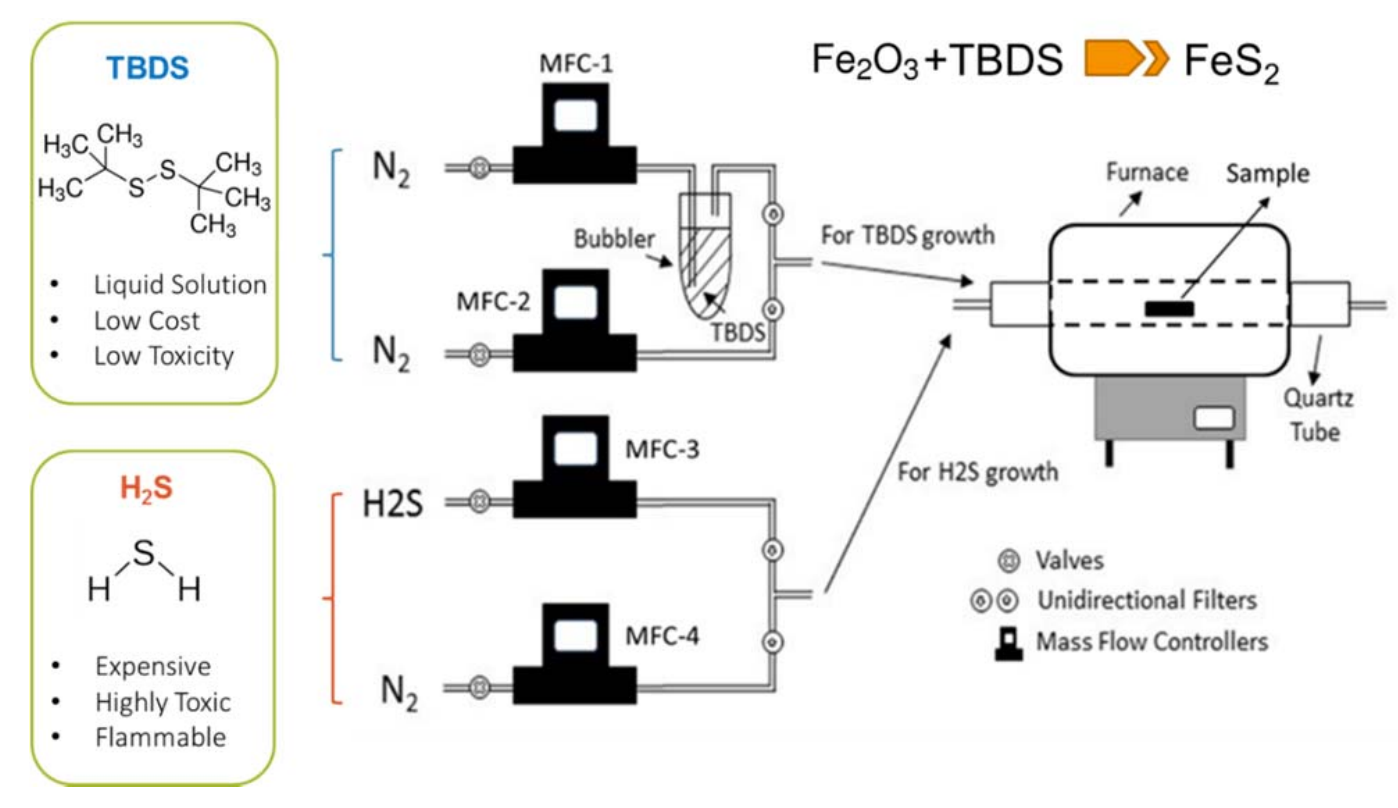

Figure 2: The TBDS and $\mathrm{H}_{2}$ S based experimental setups for sulfur annealing of iron oxides films

\subsubsection{Characterization Techniques}

The film surface morphology of the synthesized $\mathrm{FeS}_{2}$ films was imaged using a Supra 55 VP high-resolution scanning electron microscope (HR-SEM). The crystallinity of the films and their phase identification were investigated using

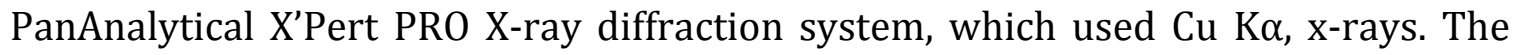
Bragg peak identification was carried out with the help of International Centre for Diffraction Data software. Compositional analysis of the surface and bulk of the sulfurized films was performed on a PHI 5000 Versaprobe XPS system from Physical Electronics, Inc. that employed monochromatic $\mathrm{Al} \mathrm{K \alpha}$ x-rays of energy $1486.6 \mathrm{eV}$. The x-ray spot size used was $200 \mu \mathrm{m}$ with power $50 \mathrm{~W}$. Pass energies used were 117 $\mathrm{eV}$ for survey scans $(0-1400 \mathrm{eV})$ and $23.5 \mathrm{eV}$ for high resolution spectra. The takeoff angle used was $45^{\circ}$. The survey scans were taken after a two minutes Ar sputter cleaning of the surface at $0.5 \mathrm{kV}$. During depth profiling, Ar sputtering at $2 \mathrm{kV}$ was 
used. High resolution transmission electron microscopy (HR-TEM) images are obtained from JEM 2100F from JOEL. Transmittance and reflectance spectra were collected using Perkin Elmer Lambda 950 UV-Vis-NIR spectrophotometer equipped with a $150 \mathrm{~mm}$ integrating sphere. Hall voltages and mobilities were measured using the van der Pauw method at $10 \mu \mathrm{A}$ current in a magnetic field of $0.6 \mathrm{~T}$. For contacts, $125 \mathrm{~nm}$ thick gold over $20 \mathrm{~nm}$ of chromium was deposited using a cryo-pump based thermal evaporator from Varian.

\subsection{Results and Discussions}

\subsubsection{Scanning electron microscopy (SEM)}
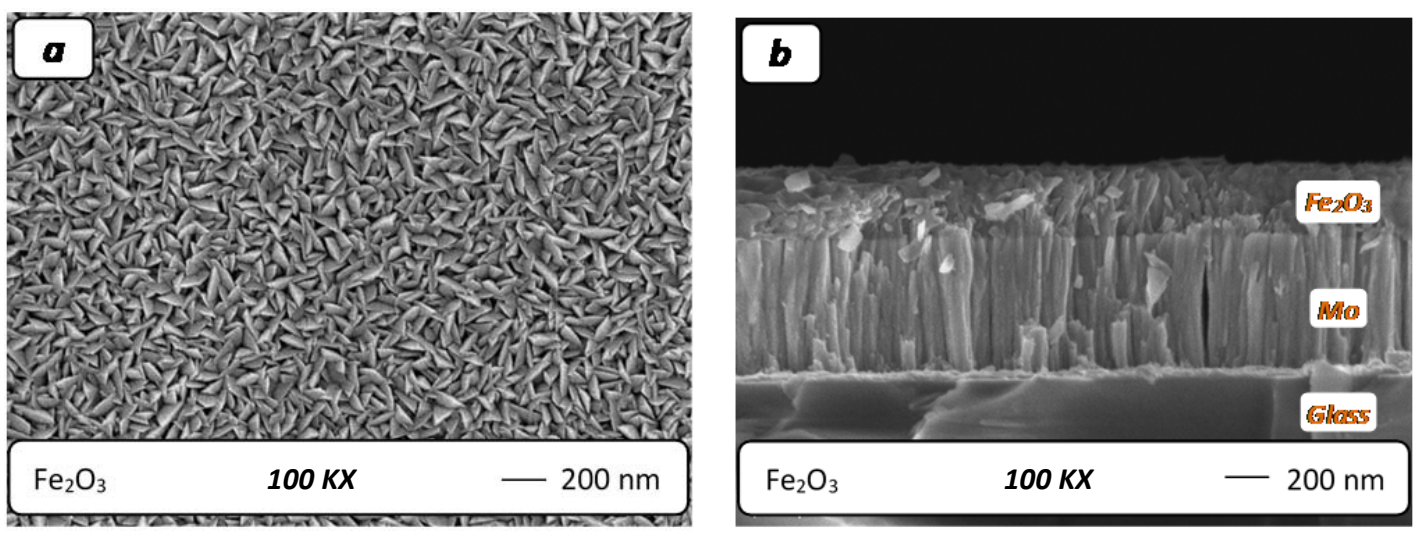

Figure 3: Sputtered oxide films grown on Mo-coated glass. a) Surface view and b) Cross-sectional view

Scanning electron microscopy images of iron oxide films sputtered on Mo sputtered glass substrate are shown in Fig. 3. Fig. 3a shows the surface of the sputtered $\mathrm{Fe}_{2} \mathrm{O}_{3}$ film on a Mo-coated glass substrate and Fig. 3b shows the corresponding cross-sectional image. The thickness of $\mathrm{Mo}$ and $\mathrm{Fe}_{2} \mathrm{O}_{3}$ are $600 \mathrm{~nm} \pm 50$ $\mathrm{nm}$ and $300 \mathrm{~nm} \pm 50 \mathrm{~nm}$ respectively. The Mo layer was used as it is a potential back contact metal for solar cell devices. 

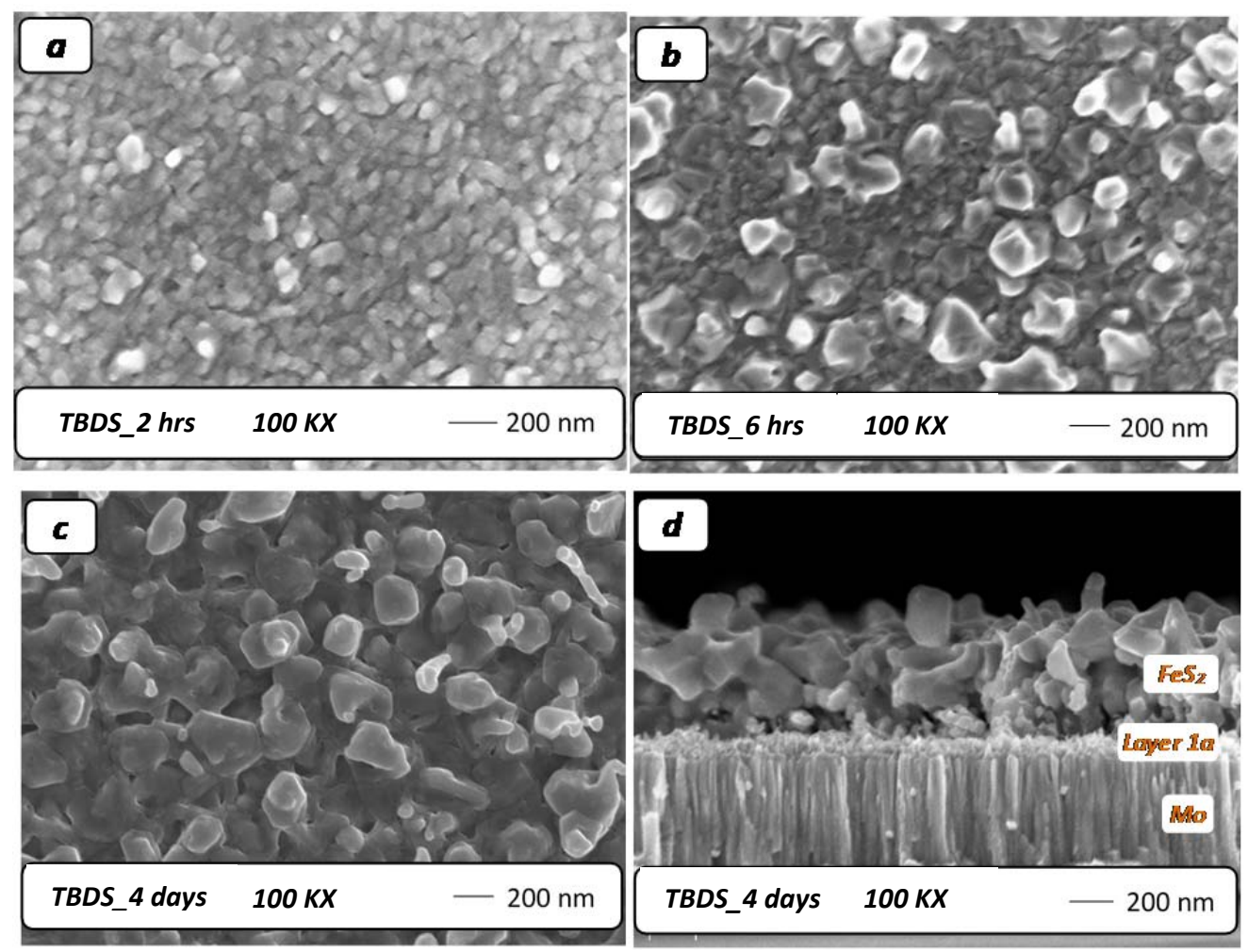

Figure 4: Sulfurized iron oxide films on Mo-coated glass substrates using TBDS setup. Surface view of the films at various annealing time periods; a) 2 hrs. b) 6 hrs. and c) 4 days. d. Cross-sectional view of the pyrite film on Mo.

The SEM images of sulfurized iron oxide thin films using TBDS setup at various annealing periods of 2 hrs, 6 hrs, and 4 days (96 hrs) are in shown in Fig. 4.a-c. As the time of annealing increased, the grains grew larger with some grains protruding higher. The cross-sectional image of the 4-day annealed sample showed compact pyrite layer (Fig.4d). The thickness of the converted iron pyrite layer was $630 \mathrm{~nm}$. A grainier thin layer (around $86 \mathrm{~nm}$ ) between iron pyrite and Mo named "Layer 1a" was also observed. This layer was sodium rich due to sodium leaching from the glass through the Mo layer. This layer could be avoided either by increasing the Mo-thickness or using a Na-blocking layer between the Mo and the oxide precursor layer. 
Fig 5. shows the images of the pyrite films obtained with $\mathrm{H}_{2} \mathrm{~S}$ annealing. Fig. $5 a$ and $5 b$ show the images of the surface and cross-sectional images of the annealed pyrite film (confirmed from XRD) grown on a bare glass substrate. The film thickness was $625 \mathrm{~nm}$. The film surface and the cross-section show distinct granular texture. When the same growth conditions were used on Mo-coated glass substrates, the surface and cross-sectional images looked compact (Fig. 5c-d). Similar to TBDS annealing, an intermediate layer just above the Mo-layer (termed "Layer 2" in Fig. 5d) was observed. However, these sulfurized films on Mo-coated glass showed several non-pyrite phases as confirmed by the XRD (See Fig.7). When $\mathrm{H}_{2} \mathrm{~S}$ was used as sulfur source, the presence of $\mathrm{Na}$ was necessary to form pyrite phase.
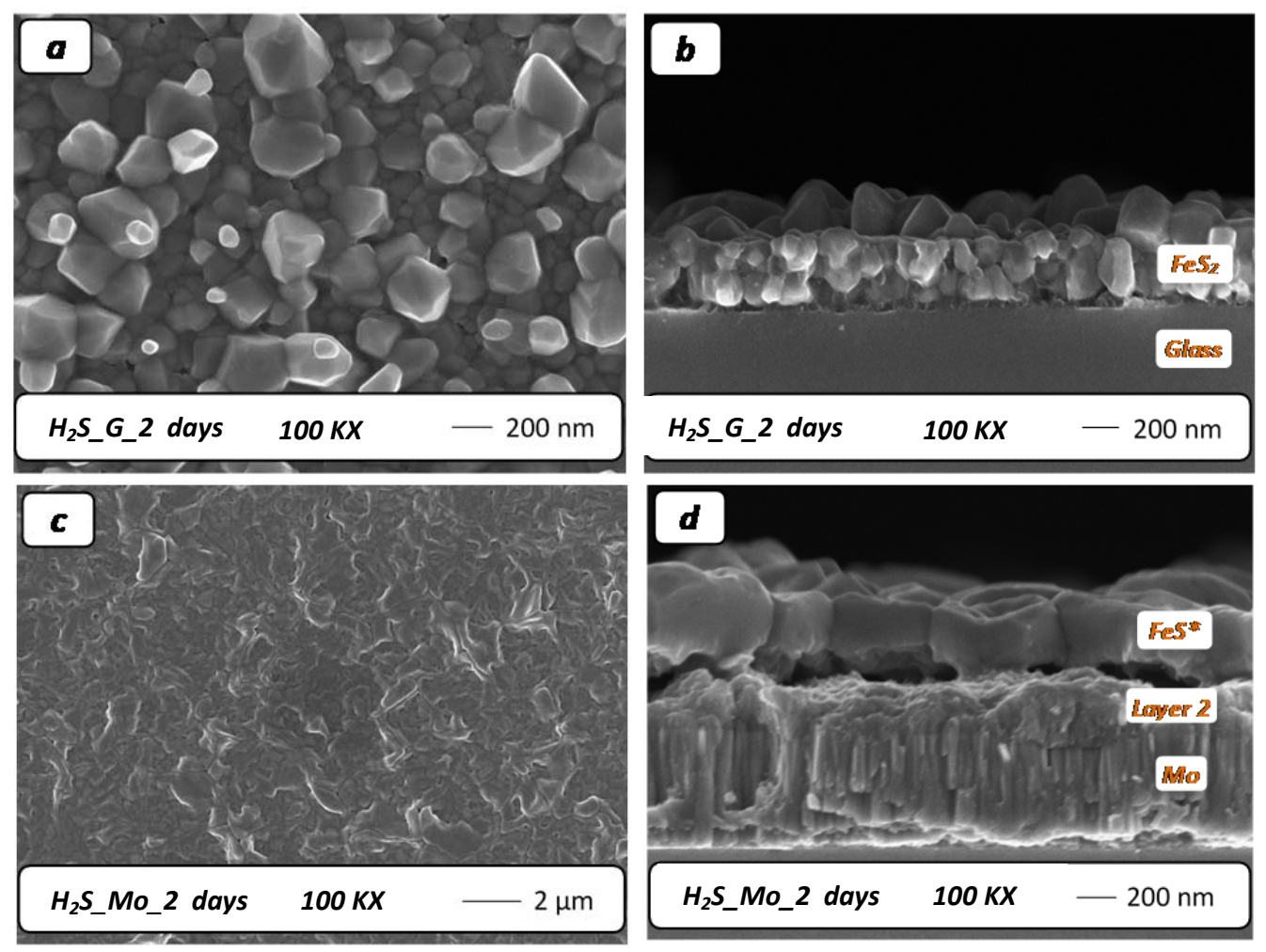

Figure 5: Sulfurized iron oxide on glass using $\mathrm{H}_{2} \mathrm{~S}$ setup a) surface and b) cross-sectional view; sulfurized iron oxide on Mo-coated glass using $\mathrm{H}_{2} \mathrm{~S}$ setup c) surface and d) cross-sectional view 


\subsubsection{X-ray Diffraction}

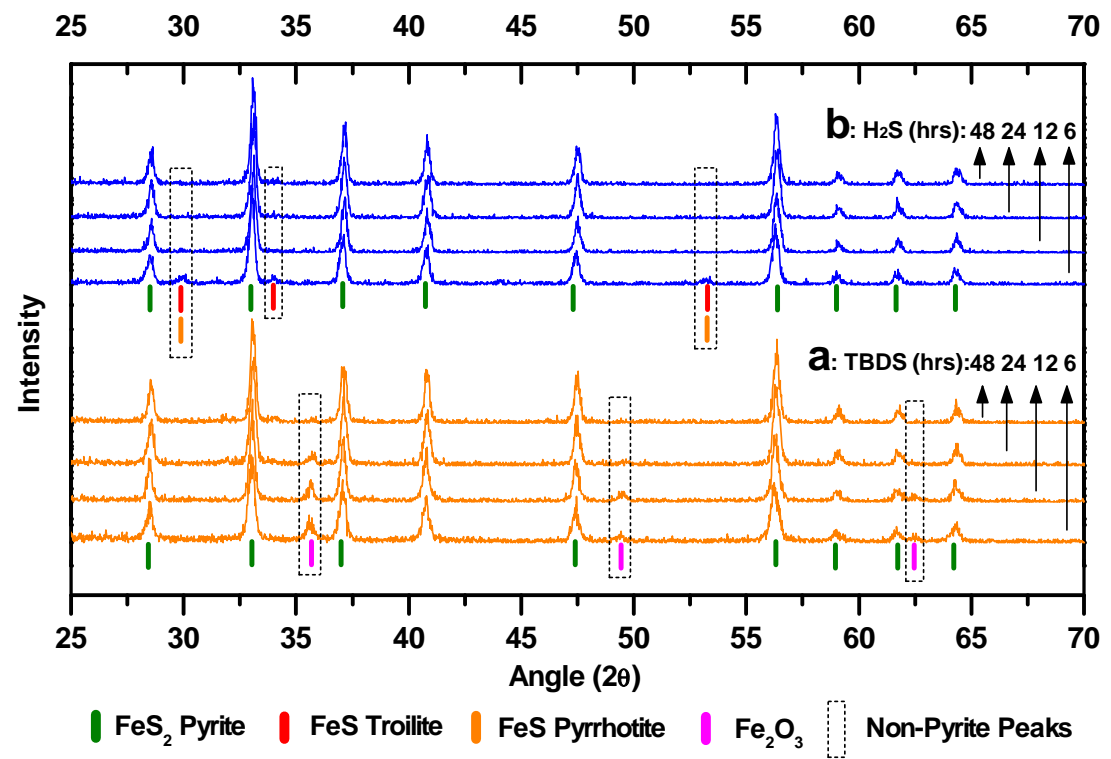

Figure 6: XRD pattern of iron sulfide thin films growth are different time periods ranging from 2 hrs. to 48 hrs. using TBDS setup (orange) and $\mathrm{H}_{2} \mathrm{~S}$ setup (blue).

XRD patterns of the thin films annealed in a) TBDS and b) $\mathrm{H}_{2} \mathrm{~S}$ setups using $\mathrm{Fe}_{2} \mathrm{O}_{3}$ thin films grown on bare glass substrates containing sodium are shown in Fig. 6. The sulfur annealing time periods have been varied from 6 hrs. to 48 hrs. to study the rate of sulfur diffusion in both setups. The TBDS sulfurized films were pyrite phase although a few $\mathrm{Fe}_{2} \mathrm{O}_{3}$ peaks were present, which disappeared slowly as the time of annealing increased. However, the conversion of oxide films into the pyrite phase was faster in case of $\mathrm{H}_{2} \mathrm{~S}$ annealing (Fig. 6b). Even for 6 hrs. annealing, no oxide phases were present although some peaks of monosulfide troilite and pyrrhotite phases with nominal intensity were observed. The phases disappeared with increases in annealing time. This implies that the conversion of $\mathrm{Fe}_{2} \mathrm{O}_{3}$ to $\mathrm{FeS}_{2}$ is slower in TBDS than in $\mathrm{H}_{2} \mathrm{~S}$. 


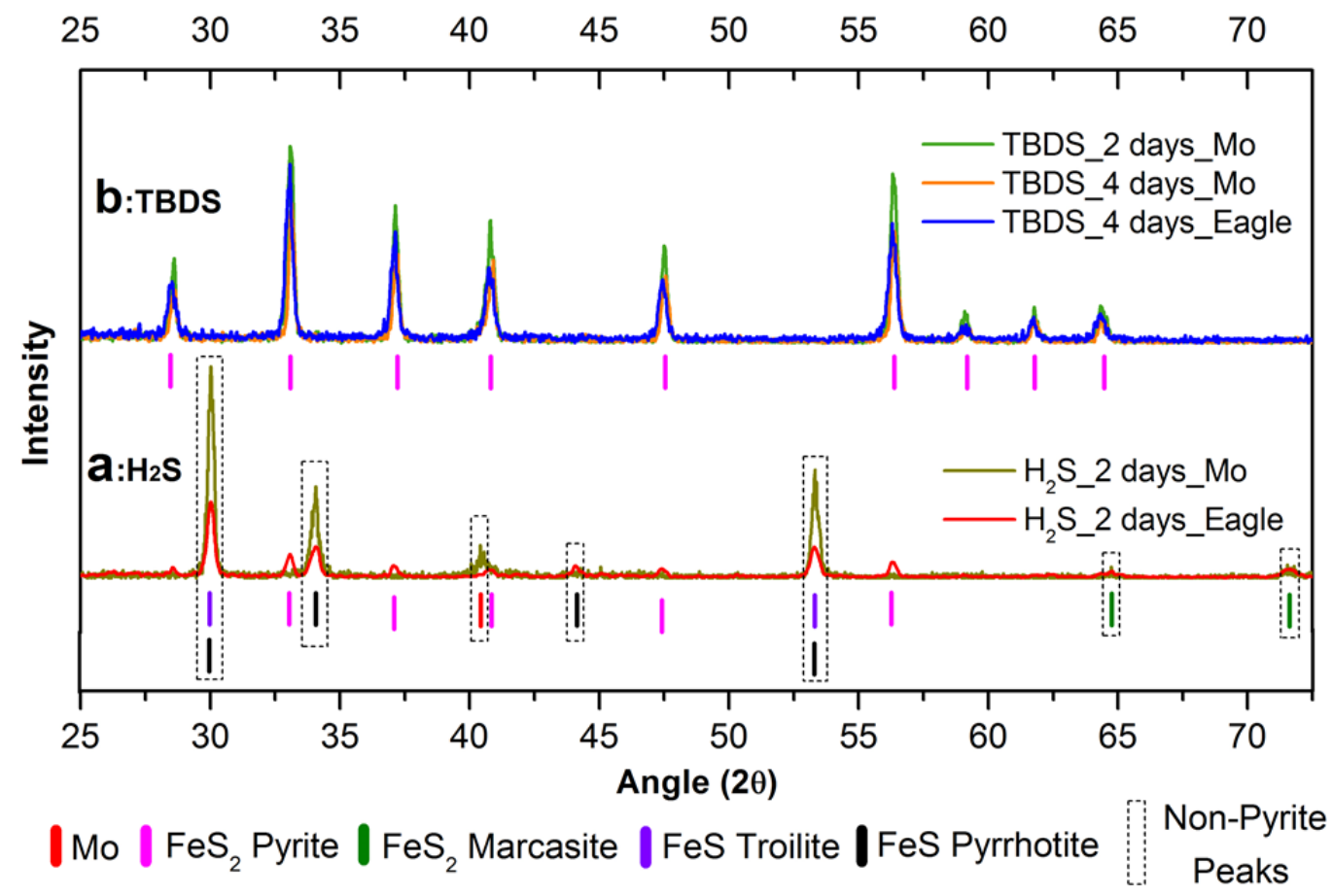

Figure 7: XRD pattern of iron sulfide thin films grown using TBDS and $\mathrm{H}_{2} \mathrm{~S}$ for 2 days and 4 days on Mo-coated glass and Corning ${ }^{\circledR}$ EAGLE XG ${ }^{\circledR}$ glass substrates.

The most important finding of this work is shown in Fig. 7. It has been reported previously that $\mathrm{Na}$ is required to form pyrite [36]. When $\mathrm{H}_{2} \mathrm{~S}$ was used, sulfurized films on Mo-coated soda-lime glass or sodium free Corning ${ }^{\circledR}$ EAGLE XG ${ }^{\circledR}$ glass showed phases other than pyrite (Fig. 7a); however, when a $\mathrm{Na}$ containing bare glass substrate was used, only the pyrite phase was observed (Fig. 6b). When TBDS was used during annealing, only pyrite phases were observed whether it was on a Na-free substrate such as Corning ${ }^{\circledR}$ EAGLE XG ${ }^{\circledR}$ glass (Fig. 7b) or a Nacontaining bare glass (Fig. 6a). Thus the presence of $\mathrm{Na}$ is not necessary for pyrite phase formation when TBDS is used for sulfurization. This is important for solar cell applications because the pyrite film has to be formed on a metallic layer, such as Mo. Berry et al. reported Marcasite phase when Mo was coated on the soda lime glass because it blocked most of the sodium required for pyrite phase formation [36]. This 
marcasite phase had to be converted back to the pyrite phase by annealing in sulfur at $550{ }^{\circ} \mathrm{C}$. However, in our work we showed that if TBDS is used as a sulfur precursor, pyrite films can be formed at lower temperature $\left(400^{\circ} \mathrm{C}\right)$ without the need of sodium.

\subsubsection{X-ray photoelectron Spectroscopy (XPS)}

The XPS spectra obtained for the sulfur S $2 p\left(2 p_{1 / 2}\right.$ and $\left.2 p_{3 / 2}\right)$ and iron Fe 2p3/2 peaks confirmed that $\mathrm{FeS}_{2}$ bonded as a pyrite phase[39]. The depth profile data was used to estimate at the ratio of the iron to sulfur and to evaluate the conversion of oxide film into pyrite phase over the entire thickness of the film.

\subsubsection{TBDS-XPS depth profiling:}
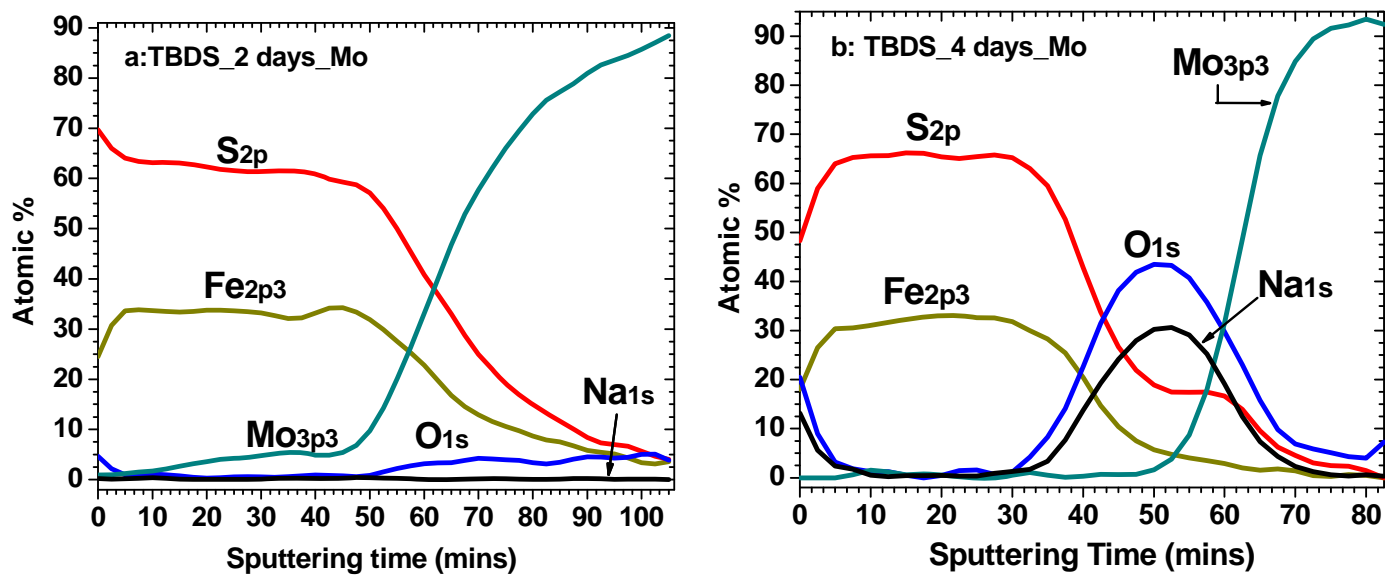

Figure 8: XPS depth profiling of a) 2 days and b) 4 days sulfur annealed iron oxide thin films on Mo glass using TBDS setup

The XPS depth profiles of 2 days (48 hrs.) and 4 days (48 hrs.) TBDSannealed $\mathrm{Fe}_{2} \mathrm{O}_{3}$ thin films on Mo-glass substrates are shown in Fig. 8a and 8b 
respectively. For $48 \mathrm{hrs}$. of annealing, the entire $300 \mathrm{~nm}$ of $\mathrm{Fe}_{2} \mathrm{O}_{3}$ film appeared sulfurized. No presence of oxygen (01s peak) was seen before the rise of Mo3p3 indicating the beginning of the Mo-layer (Fig. 8a). However, the sulfur to iron atomic ratio was $<2.0$ (Fig.9) indicating the presence of some amorphous FeS phases within the film which wasn't possible to detect by XRD (See Fig.7b). A small quantity of Mo (less than $5 \%$ ) in the bulk of the film was observed. The rise of 01s at the interface of $\mathrm{Fe}_{2} \mathrm{O}_{3}$ and $\mathrm{Mo}$ and the presence of the sulfur peak indicate the presence of $\mathrm{MoS}_{2}$ and/or some mixed phase such as $\mathrm{MoO}_{\mathrm{x}} \mathrm{S}_{2-\mathrm{x}}$ as suggested in the work previously reported $[18,40]$.

When the annealing time period was increased to 4 days (96 hrs.) under the same growth conditions, the $\mathrm{S} / \mathrm{Fe}$ ratio in the bulk was close to the desired value of 2.0 (See Fig. $8 \mathrm{~b}$ and 9). The S/Fe ratio was slightly greater than 2.0 at the surface of the film. This could be due to the presence of excess elemental sulfur resulting from the decomposition of the organic precursor TBDS. Another interesting fact is the absence of the Mo3p3 peak in the bulk of the pyrite film for the 4 days annealed case (Fig. 8b). There was some presence of Mo in the bulk of the film for 2 days annealed sample as shown in Fig. 8a. The presence of Mo in the 2 days-annealed film could be due to a slightly more porous intermediate layer compared to the 4 days-annealed film (compare Fig. 10c and Fig. 10d). In addition, sodium presence is significant in the 4 days-annealed film between the pyrite and Mo layer. This indicates the migration of sodium from the glass through the Mo-layer when the temperature is maintained for a prolonged period [36,41]. Such a high content of $\mathrm{Na}$ was not detected in 2 days annealed film. 


\subsubsection{S:Fe ratio with thin film depth}

The XPS depth profiling was also performed for $\mathrm{H}_{2} \mathrm{~S}$ annealed film on both bare glass and Mo-coated glass substrates. The S:Fe stoichiometry was monitored to observe the impact of the TBDS and $\mathrm{H}_{2} \mathrm{~S}$ growth methods with respect to annealing time periods. The ratios are depicted in Fig. 9.

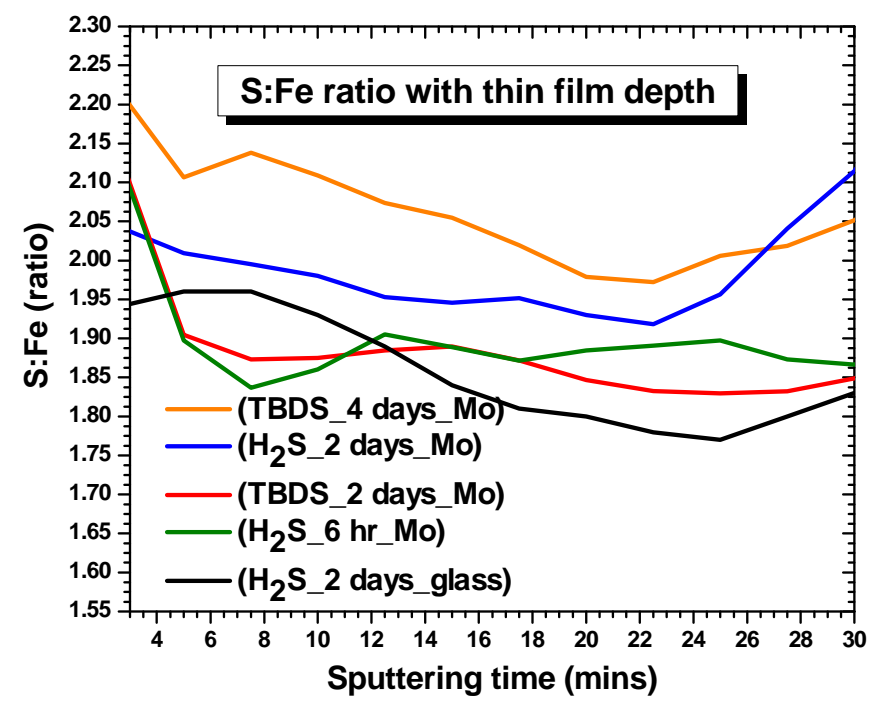

Figure 9: Graph indicating the FeS2 stoichiometry with thin film depth (bulk composition) of various samples

Overall, the increase in sulfur annealing time increased the atomic ratio closer to 2. In case of TBDS annealing, the film annealed for 4 days maintained the average Se:F ratio at 2 . As mentioned earlier, the ratio was above 2 on the surface. The ratio was slightly less than 2 for the 2 days TBDS annealed film.

When $\mathrm{H}_{2} \mathrm{~S}$ was used as the sulfur source, the sulfurized films on Mo-coated glass didn't show the pyrite phase (Fig. 7). Although the Se:Fe ratio was fairly close 
to 2 for 2-days $\mathrm{H}_{2} \mathrm{~S}$ annealed film, the phase was not pyrite. On the other hand, the film grown on a Na-containing bare glass annealed for same time in $\mathrm{H}_{2} \mathrm{~S}$ environment showed pyrite phase, but was clearly sulfur deficient (Black curve in Fig.9).

\subsubsection{Raman Spectroscopy}

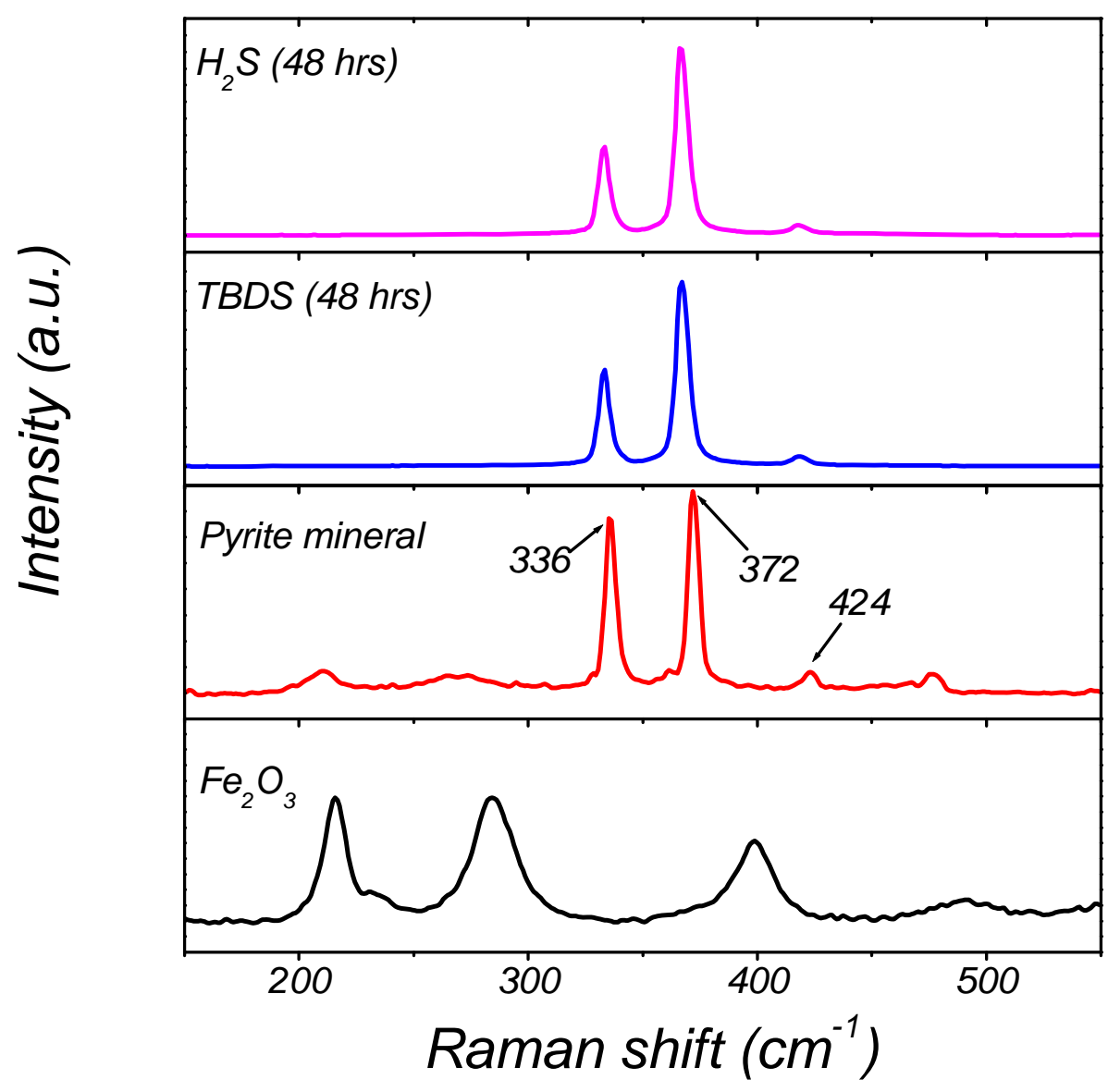

Figure 10: Raman Spectra of iron oxide, pyrite mineral and pyrite films (on soda lime glass substrate) annealed in TBDS and $\mathrm{H}_{2} \mathrm{~S}$ respectively for $48 \mathrm{hrs}$.

Raman spectra were obtained for the as-deposited $\mathrm{Fe}_{2} \mathrm{O}_{3}$ and annealed pyrite films using a $532 \mathrm{~nm}$ laser. Fig. 11 shows the Raman peaks for both TBDS and $\mathrm{H}_{2} \mathrm{~S}$ 
annealed pyrite films on soda lime glass substrates (c.f. XRD graph of Fig. 6), which matched nearly perfectly with the peaks at $336 \mathrm{~cm}^{-1}, 372 \mathrm{~cm}^{-1}$, and $424 \mathrm{~cm}^{-1}$ of the pyrite mineral. These peaks also matched with the reported values for pyrite films $[9,29,36,42]$. In addition, the annealed pyrite films did not show any peaks corresponding to the precursor $\mathrm{Fe}_{2} \mathrm{O}_{3}$ film or the impurity phase such as marcasite $[42]$.

\subsubsection{High-resolution transmission electron microscopy (HRTEM)}
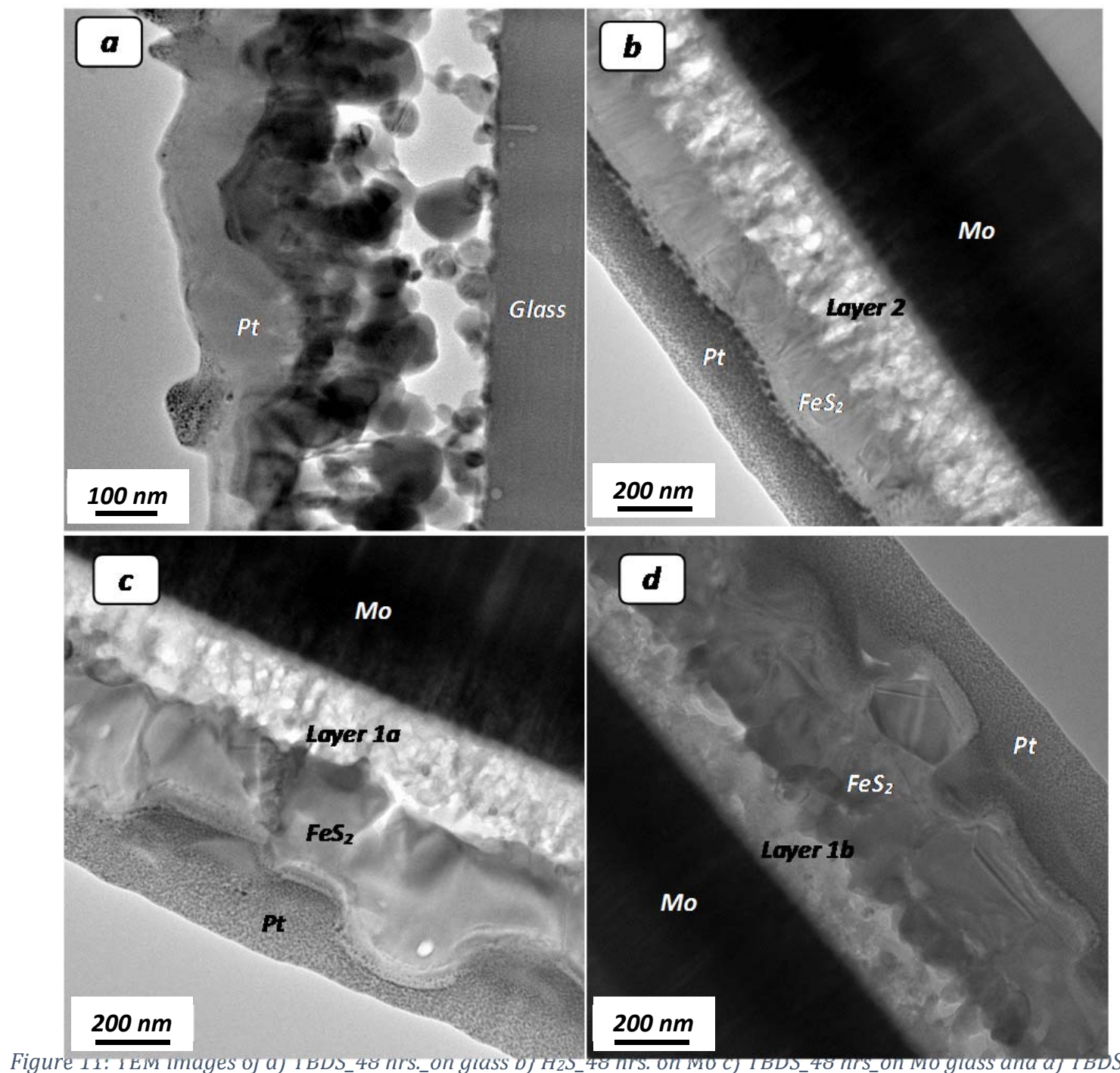

days_on Mo glass 
Figure 11 shows the TEM cross-sectional images of Pyrite film grown on glass and Mo using TBDS and $\mathrm{H}_{2} \mathrm{~S}$ for $48 \mathrm{hrs}$. and 96 hours. The film grown on the bare glass (Fig.11a) is highly porous but with the Mo-layer, the films were fairly compact (Fig. 11b, c, and d). The TBDS annealed film became more compact when the time of annealing increased from $48 \mathrm{hrs}$. to $96 \mathrm{hrs}$. (4 days) (Fig. 11c and d). The 48 hrs. annealed film in both $\mathrm{H}_{2} \mathrm{~S}$ and TBDS environments had similar appearances in terms of the compactness of the layers, but the film annealed in $\mathrm{H}_{2} \mathrm{~S}$ showed multiple phases like marcasite and troilite instead of pyrite (Fig. 7). The presence of marcasite phase was also confirmed by the TEM electron beam (e-beam) diffraction image as shown in Fig. 12.

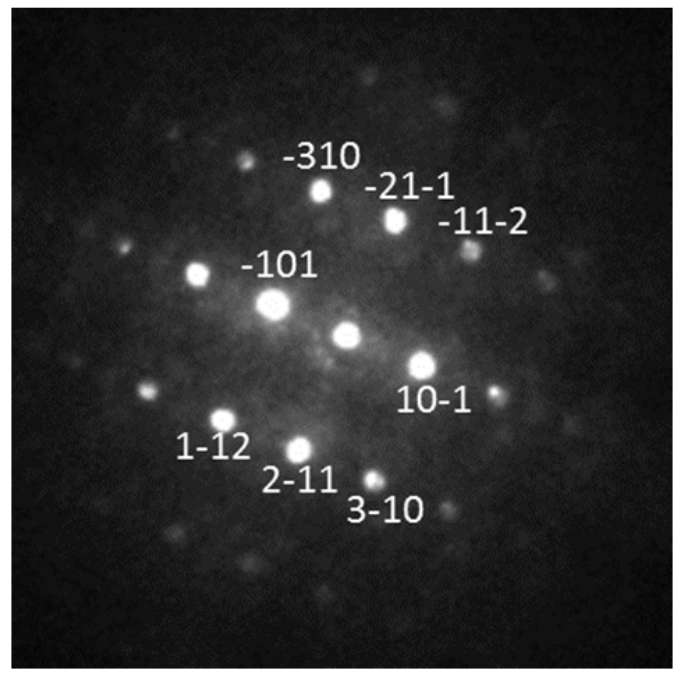

Figure 12: TEM e-beam diffraction of $\mathrm{H}_{2} \mathrm{~S}$ grown film on Mo-coated glass indicating [131] zone axis of marcasite and the Bragg's reflections.

On the other hand, TEM e-beam diffraction obtained for 4-days TBDS annealed film confirmed pyrite structure as shown in Fig. 13(a) and (b). The pyrite phase of the films on Mo-coated glass sulfurized in TBDS sulfur source was also confirmed by XRD measurement (Fig. 7b). 

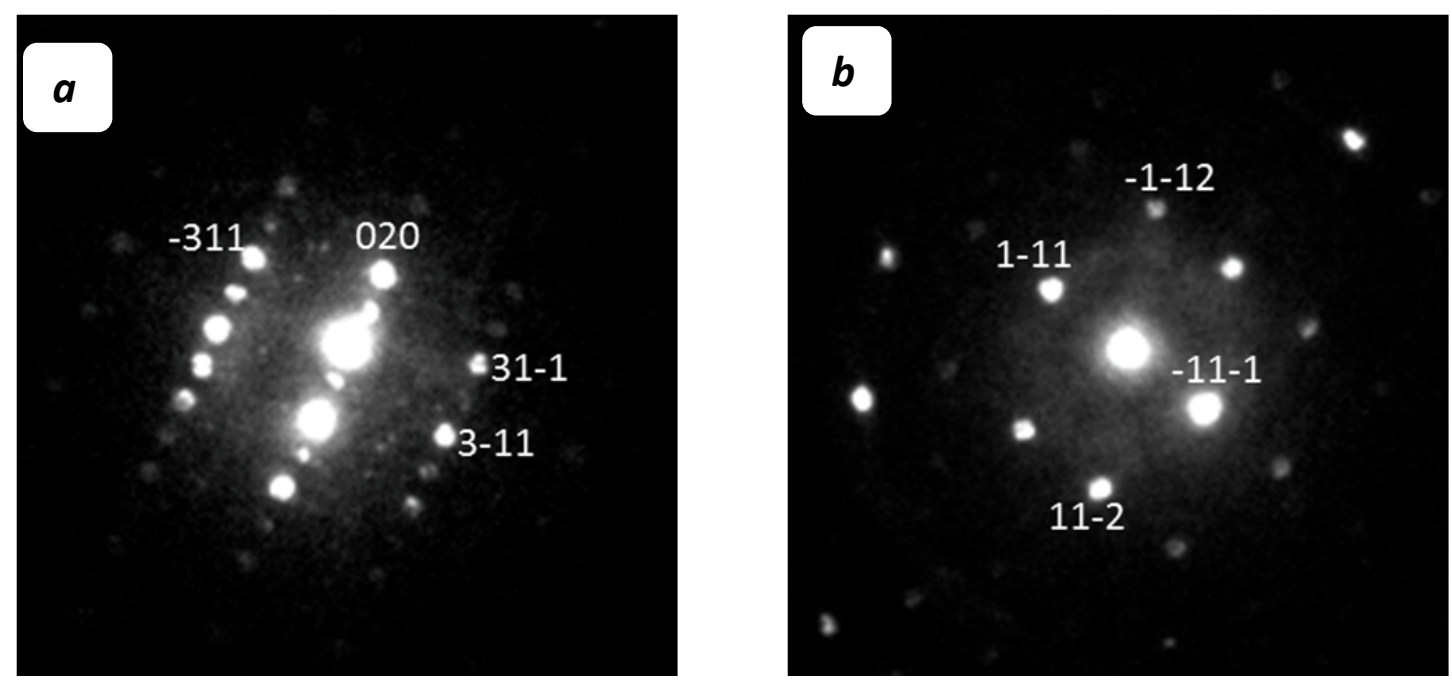

Figure 13: TEM e-beam diffraction of TBDS grown film on Mo-coated glass substrate indicating (a) [103] and (b) [132] zone axis of pyrite and their corresponding Bragg's reflections

\subsubsection{Optical Properties}

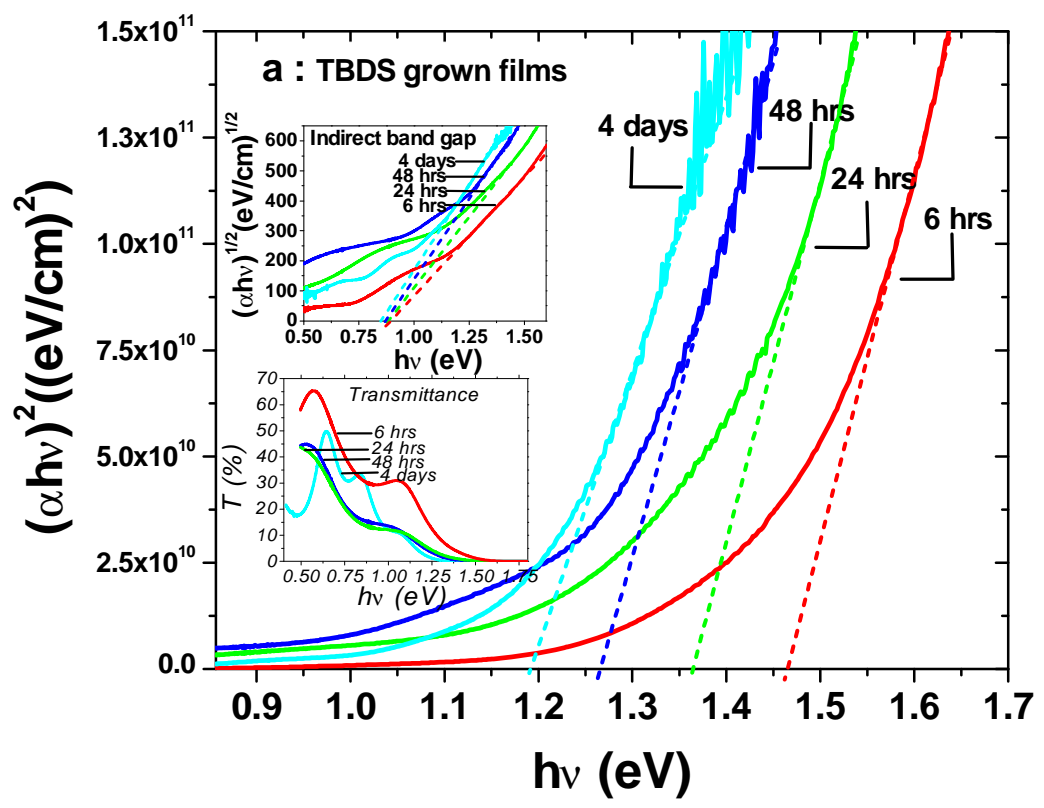




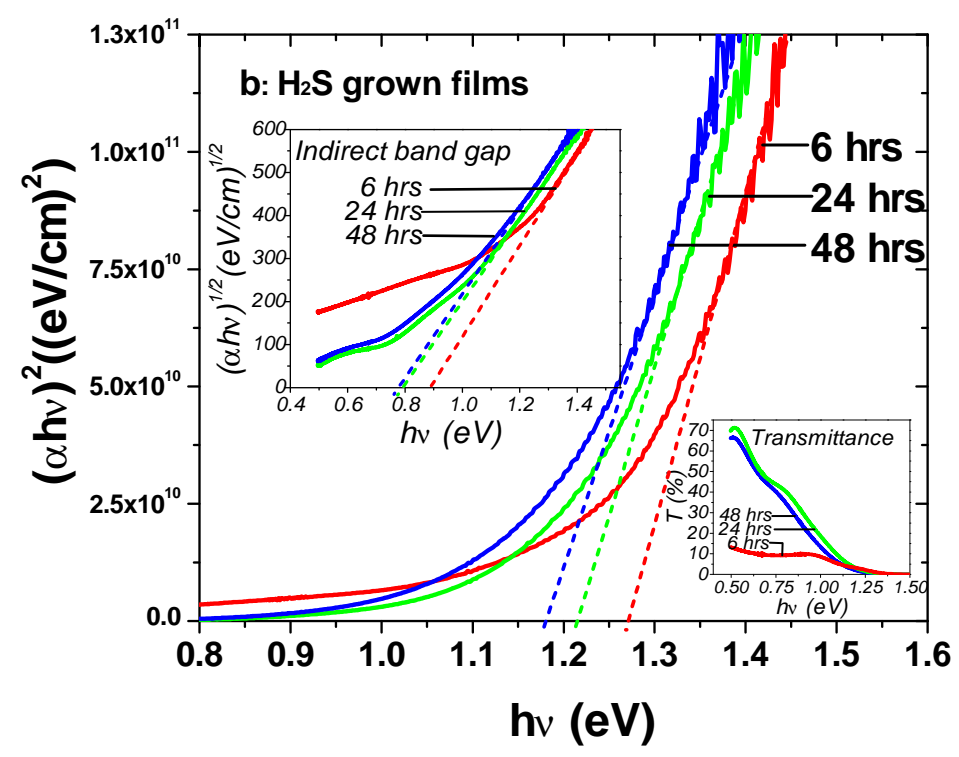

Figure 14: Graphs indicating the optical characteristics of iron sulfide films grown at various time periods in a. TBDS and b. $\mathrm{H}_{2} \mathrm{~S}$ atmosphere. The insets show plots for indirect band gaps and the transmittance.

The optical properties of TBDS and $\mathrm{H}_{2} \mathrm{~S}$ growth models are shown in Fig. 14. For TBDS grown films shown in Fig.14a, the direct bandgap of the thin films, as obtained from the Tauc plot [43] decreased from $1.46 \mathrm{eV}$ to $1.19 \mathrm{eV}$ as the annealing time period increased from 6hrs. to 4 days (96hrs). The band gap of $1.19 \mathrm{eV}$ for 96 hrs. annealed film matches with the direct band gap of pyrite confirming the complete conversion of $\mathrm{Fe}_{2} \mathrm{O}_{3}$ precursor film into the pyrite phase $[9,42]$. The indirect band gaps were assessed by $(\alpha h v)^{1 / 2}$ vs. $h v$ plot. The indirect band gaps for $6 \mathrm{hrs}, 24 \mathrm{hrs}, 48 \mathrm{hrs}$, and 4 days annealed films were $0.9 \mathrm{eV}, 0.89 \mathrm{eV}, 0.87 \mathrm{eV}$, and $0.85 \mathrm{eV}$ respectively (See inset of Fig. 14a). These values are in the same range as the pyrite indirect bandgaps reported earlier [3,42]. As shown in Fig.14b, the bandgap of the films grown with $\mathrm{H}_{2} \mathrm{~S}$ decreased from $1.27 \mathrm{eV}$ to $1.18 \mathrm{eV}$ with the increase in annealing time period from 6 hrs. to 48 hrs. In both cases, the initial presence of oxides led to high bandgap values but with longer sulfur annealing, the 
entire film converted to pyrite and the bandgaps (1.19 eV for TBDS and $1.18 \mathrm{eV}$ for $\mathrm{H}_{2} \mathrm{~S}$ ) corresponded to the pyrite phase [42]. As shown in the Fig. 14b inset, the indirect band gaps obtained for $\mathrm{H}_{2} \mathrm{~S}$ annealed films were slightly lower $(0.89 \mathrm{eV}$ for $6 \mathrm{hrs}, 0.79$ for $24 \mathrm{hrs}$, and $0.78 \mathrm{eV}$ for $48 \mathrm{hrs}$ ) than those for the TBDS films.

\subsubsection{Optical images of the grown pyrite films}
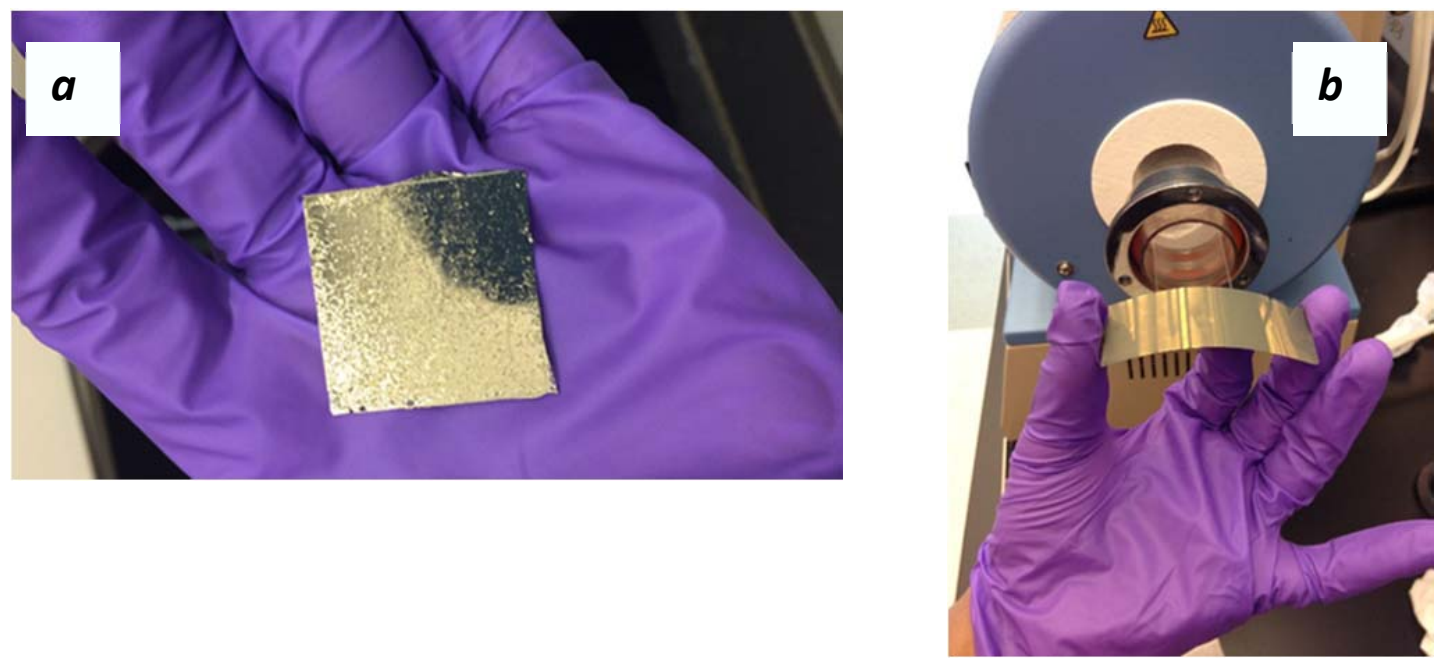

Figure 15: (a) Pyrite grown on Corning ${ }^{\circledR}$ EAGLE X $G^{\circledR}$ glass; (b) Pyrite thin film grown on flexible Corning ${ }^{\circledR}$ Willow ${ }^{\circledR}$ Glass

The films grown on a rigid Corning ${ }^{\circledR}$ EAGLE XG $^{\circledR}$ glass and a flexible Corning ${ }^{\circledR}$ Willow $^{\circledR}$ Glass substrates can be seen in Fig. 15. Both films show characteristic goldlike luster of pyrite crystals. As most of the solar industry is moving towards flexible substrates, we wanted to observe the compatibility of our pyrite growth on $100 \mathrm{~m}$ thick flexible Corning ${ }^{\circledR}$ Willow ${ }^{\circledR}$ Glass. As shown in Fig. 15b, we confirmed the viability of the pyrite growth process on the flexible glass substrate as well. 


\subsubsection{Electrical properties}

The electrical properties of the grown pyrite samples assessed by using Hall Effect measurement technique and the measured data are depicted in Table I. Three samples, two TBDS and one $\mathrm{H}_{2} \mathrm{~S}$ grown, were used for this measurement. All these three samples were grown on bare glass substrate and all were pyrite phase confirmed by the XRD measurements. Our measurements showed all the samples $p$ type as expected.

Table I: Electrical characterization of thin films grown using TBDS and $\mathrm{H}_{2} \mathrm{~S}$ setups

\begin{tabular}{ccccc}
\hline Sample & $\begin{array}{c}\text { Hall } \\
\text { Mobility } \\
\left(\mathrm{cm}^{2} / \mathrm{V}-\mathrm{sec}\right)\end{array}$ & $\begin{array}{c}\text { Sheet } \\
\text { resistance } \\
(\Omega / \mathrm{sq})\end{array}$ & $\begin{array}{c}\text { Career } \\
\text { Concentration } \\
\left(\mathrm{cm}^{-3}\right)\end{array}$ & $\begin{array}{c}\text { Conductivity } \\
(\mathrm{S} / \mathrm{cm})\end{array}$ \\
\hline TBDS_2 days & 0.09 & 10053.16 & $2.13 \times 10^{20}$ & 3.06 \\
\hline TBDS_4 days & 0.27 & 18530.87 & $3.89 \times 10^{19}$ & 1.68 \\
\hline $\mathrm{H}_{2} \mathrm{~S} \_2$ days & 0.05 & 21366.64 & $1.67 \times 10^{20}$ & 1.44 \\
\hline
\end{tabular}

Our champion sample (TBDS_4 days) had the highest mobility value of $0.27 \mathrm{~cm}^{2} / \mathrm{V}$ sec compared to $0.05 \mathrm{~cm}^{2} / \mathrm{V}$-sec for $\mathrm{H}_{2} \mathrm{~S} \_2$ days and $0.08 \mathrm{~cm}^{2} / \mathrm{V}$-sec for TBDS_2 days films. The carrier densities were in the order of $10^{19} \mathrm{~cm}^{-3}$ to $10^{20} \mathrm{~cm}^{-3}$.

\subsection{Conclusions}

To conclude, we have synthesized high quality iron pyrite thin films using a one-step sulfur annealing using a low cost organic sulfur source, TBDS. Pyrite phase purity has been obtained with stoichiometric stability by having Se:F atomic percentage ratio maintained at 2.0. Comparing the TBDS with $\mathrm{H}_{2} \mathrm{~S}$, TBDS is the 
better choice for sulfurization because with TBDS presence of sodium is not necessary for pyrite formation. $\mathrm{H}_{2} \mathrm{~S}$, while more reactive, does not yield pure pyrite phase when grown on metal-coated substrates. Importantly, for the pyrite phase formation, $\mathrm{H}_{2} \mathrm{~S}$ is dependent on sodium presence whereas TBDS is independent of the availability of sodium. The optical bandgap measurement confirmed pyrite direct band gap values; $1.19 \mathrm{eV}$ for TBDS and $1.18 \mathrm{eV} \mathrm{H}_{2} \mathrm{~S}$ annealed films.

\section{Acknowledgements}

This study was supported by the Office of Naval Re- search; Grant No. N00014-11-10658.

\subsection{References}

[1] C. Wadia, A.P. Alivisatos, D.M. Kammen, Materials Availability Expands the Opportunity for Large-Scale Photovoltaics Deployment, Environ. Sci. Technol. 43 (2009) 2072-2077. doi:10.1021/es8019534.

[2] C. Wadia, Y. Wu, S. Gul, S.K. Volkman, J. Guo, A.P. Alivisatos, SurfactantAssisted Hydrothermal Synthesis of Single Phase Pyrite FeS2 Nanocrystals, Chem. Mater. 21 (2009) 2568-2570. doi:10.1021/cm901273v.

[3] G. Smestad, A. Ennaoui, S. Fiechter, H. Tributsch, W.K. Hofmann, M. Birkholz, W Kautel, Photoactive thin film semiconducting iron pyrite prepared by sulfurization of iron oxides, Sol. Energy Mater. 20 (1990) 149-165. doi:10.1016/0165-1633(90)90001-H.

[4] A. Ennaoui, S. Fiechter, C. Pettenkofer, N. Alonso-Vante, K. Büker, M. Bronold, Ch. Höpfner, H. Tributsch , Iron disulfide for solar energy conversion, Sol. Energy Mater. Sol. Cells. 29 (1993) 289-370. doi:10.1016/09270248(93)90095-K.

[5] S. Fiechter, J. Mai, A. Ennaoui, W. Szacki, Chemical vapour transport of pyrite (FeS2) with halogen (Cl, Br, I), J. Cryst. Growth. 78 (1986) 438-444. doi:10.1016/0022-0248(86)90144-2.

[6] S. Fiechter, M. Birkholz, A. Hartmann, P. Dulski, M. Giersig, H. Tributsch, R.J.D. Tilley, The microstructure and stoichiometry of pyrite FeS2-x, J. Mater. Res. 7 (1992) 1829-1838. doi:10.1557/JMR.1992.1829. 
[7] M. Cabáan-Acevedo, N.S. Kaiser, C.R. English, D. Liang, B.J. Thompson, H.E. Chen, K. J. Czech, J. C. Wright, R. J. Hamers, and S. Jin, Ionization of high-density deep donor defect states explains the low photovoltage of iron pyrite single crystals, J. Am. Chem. Soc. 136 (2014) 17163-17179. doi:10.1021/ja509142w.

[8] A. Ennaoui; S. Fiechter; G. Smestad; H. Tributsch, Preparation of Iron Disulfide and its use for Solar Energy Conversion, World Renew. Energy Congr. 1 (1990) 458-464.

[9] Y. Bi, Y. Yuan, C.L. Exstrom, S.A. Darveau, J. Huang, Air stable, photosensitive, phase pure iron pyrite nanocrystal thin films for photovoltaic application, Nano Lett. 11 (2011) 4953-4957. doi:10.1021/nl202902z.

[10] G. Willeke, R. Dasbach, B. Sailer, E. Bucher, Thin pyrite (FeS2) films prepared by magnetron sputtering, Thin Solid Films. 213 (1992) 271-276. doi:10.1016/0040-6090(92)90293-K.

[11] A. Yamamoto, M. Nakamura, A. Seki, E.L. Li, A. Hashimoto, S. Nakamura, Pyrite (FeS2) thin films prepared by spray method using FeSO4 and (NH4)2Sx, Sol. Energy Mater. Sol. Cells. 75 (2003) 451-456. doi:10.1016/S09270248(02)00205-2.

[12] G. Smestad, A. Da Silva, H. Tributsch, S. Fiechter, M. Kunst, N. Meziani, M. Birkholz, Formation of semiconducting iron pyrite by spray pyrolysis, Sol. Energy Mater. 18 (1989) 299-313. doi:10.1016/0165-1633(89)90044-0.

[13] A.K. Raturi, L. Ndjeli, K. Rabah, FeS2 thin films prepared by spray pyrolysis, Renew. Energy. 11 (1997) 191-195. doi:10.1016/S0960-1481(96)00123-1.

[14] G. Chatzitheodorou, S. Fiechter, R. Könenkamp, M. Kunst, W. Jaegermann, H. Tributsch, Thin photoactive FeS2 (pyrite) films, Mater. Res. Bull. 21 (1986) 1481-1487. doi:10.1016/0025-5408(86)90088-7.

[15] J. Oertel, K. Ellmer, W. Bohne, J. Röhrich, H. Tributsch, Growth of n-type polycrystalline pyrite (FeS2) films by metalorganic chemical vapour deposition and their electrical characterization, J. Cryst. Growth. 198-199 (1999) 1205-1210. doi:10.1016/S0022-0248(98)01074-4.

[16] L. Samad, M. Cab??n-Acevedo, M.J. Shearer, K. Park, R.J. Hamers, S. Jin, Direct chemical vapor deposition synthesis of phase-pure iron pyrite (FeS2) thin films, Chem. Mater. 27 (2015) 3108-3114. doi:10.1021/acs.chemmater.5b00664.

[17] S. Nakamura, A. Yamamoto, Electrodeposition of pyrite(FeS2) thin films for photovoltaic cells, Sol. Energy Mater. Sol. Cells. 65 (2001) 79-85. doi:10.1016/S0927-0248(00)00080-5.

[18] S. Seefeld, M. Limpinsel, Y. Liu, N. Farhi, A. Weber, Y. Zhang, N. Berry, Y. J. Kwon, C. L. Perkins, J. C. Hemminger, R. Wu, and M. Law, Iron Pyrite Thin Films Synthesized from an Fe(acac)3 Ink, J. Am. Chem. Soc. 135 (2013) 44124424. doi:10.1021/ja311974n. 
[19] J. Joo, H. Bin Na, T. Yu, J.H. Yu, Y.W. Kim, F. Wu, J. Z. Zhang, T. Hyeon, Generalized and Facile Synthesis of Semiconducting Metal Sulfide Nanocrystals, J. Am. Chem. Soc. 125 (2003) 11100-11105. doi:10.1021/ja0357902.

[20] Y.-Y. Lin, D.-Y. Wang, H.-C. Yen, H.-L. Chen, C.-C. Chen, C.-M. Chen, C.-Y. Tang, C.-W. Chen, Extended red light harvesting in a poly(3-hexylthiophene)/iron disulfide nanocrystal hybrid solar cell, Nanotechnology. 20 (2009) 405207. doi:10.1088/0957-4484/20/40/405207.

[21] J. Puthussery, S. Seefeld, N. Berry, M. Gibbs, M. Law, Colloidal Iron Pyrite (FeS2) Nanocrystal Inks for Thin-Film Photovoltaics, J. Am. Chem. Soc. 133 (2011) 716-719. doi:10.1021/ja1096368.

[22] R. Wu, Y.F. Zheng, X.G. Zhang, Y.F. Sun, J.B. Xu, J.K. Jian, Hydrothermal synthesis and crystal structure of pyrite, 266 (2004) 523-527. doi:10.1016/j.jcrysgro.2004.02.020.

[23] C. de las Heras, I.J. Ferrer, C. Sanchez, Temperature dependence of the optical absorption edge of pyrite FeS2 thin films, J. Phys. Condens. Matter. 6 (1994) 10177. doi:10.1088/0953-8984/6/46/033.

[24] C. De las Heras, I.J. Ferrer, C. Sánchez, Comparison of pyrite thin films obtained from Fe and natural pyrite powder, Appl. Surf. Sci. 50 (1991) 505509. doi:10.1016/0169-4332(91)90227-B.

[25] B. Thomas, C. Höpfner, K. Ellmer, S. Fiechter, H. Tributsch, Growth of FeS2 (pyrite) thin films on single crystalline substrates by low pressure metalorganic chemical vapour deposition, J. Cryst. Growth. 146 (1995) 630635. doi:10.1016/0022-0248(94)00528-1.

[26] C. Höpfner, K. Ellmer, A. Ennaoui, C. Pettenkofer, S. Fiechter, H. Tributsch, Stoichiometry-, phase- and orientation-controlled growth of polycrystalline pyrite (FeS2) thin films by MOCVD, J. Cryst. Growth. 151 (1995) 325-334. doi:10.1016/0022-0248(95)00066-6.

[27] D.M. Schleich, H.S.W. Chang, Iron pyrite and iron marcasite thin films prepared by low pressure chemical vapor deposition, J. Cryst. Growth. 112 (1991) 737-744. doi:10.1016/0022-0248(91)90130-W.

[28] R.A. Berner, Iron Sulfides Formed from Aqueous Solution at Low Temperatures and Atmospheric Pressure, J. Geol. 72 (1964) 293-306.

[29] R. Morrish, R. Silverstein, C. a Wolden, Synthesis of stoichiometric FeS2 through plasma-assisted sulfurization of Fe2O3 nanorods., J. Am. Chem. Soc. 134 (2012) 17854-7. doi:10.1021/ja307412e.

[30] N. Hamdadou, A. Khelil, J.C. Bernède, Pyrite FeS2 films obtained by sulphuration of iron pre-deposited films, Mater. Chem. Phys. 78 (2003) 591601. doi:10.1016/S0254-0584(01)00577-6.

[31] X. Zhang, M. Manno, A. Baruth, M. Johnson, E.S. Aydil, C. Leighton, Crossover from nanoscopic intergranular hopping to conventional charge transport in 
pyrite thin films, ACS Nano. 7 (2013) 2781-2789. doi:10.1021/nn4003264.

[32] J. Hu, Y. Zhang, M. Law, R. Wu, Increasing the Band Gap of Iron Pyrite by Alloying with Oxygen, J. Am. Chem. Soc. 134 (2012) 13216-13219. doi:10.1021/ja3053464.

[33] B. Thomas, K. Ellmer, M. Müller, C. Höpfner, S. Fiechter, H. Tributsch, Structural and photoelectrical properties of FeS2 (pyrite) thin films grown by MOCVD, J. Cryst. Growth. 170 (1997) 808-812. doi:10.1016/S00220248(96)00600-8.

[34] C. Steinhagen, T.B. Harvey, C.J. Stolle, J. Harris, B.A. Korgel, Pyrite Nanocrystal Solar Cells: Promising, or Fool's Gold?, J. Phys. Chem. Lett. 3 (2012) 23522356. doi:10.1021/jz301023c.

[35] L. Reijnen, B. Meester, A. Goossens, J. Schoonman, In Situ Mass Spectrometric Study of Pyrite (FeS[sub 2]) Thin Film Deposition with Metallorganic Chemical Vapor Deposition, J. Electrochem. Soc. 147 (2000) 1803. doi:10.1149/1.1393437.

[36] N. Berry, M. Cheng, C.L. Perkins, M. Limpinsel, J.C. Hemminger, M. Law, Atmospheric-Pressure Chemical Vapor Deposition of Iron Pyrite Thin Films, (2012) 1-12. doi:10.1002/aenm.201200043.

[37] G. Kullerud, Phase relations in the Fe-SO system, Carnegie Inst. Wash. Yearb. 56 (1957) 198-200.

[38] S. Garner, S. Glaesemann, X. Li, Ultra-slim flexible glass for roll-to-roll electronic device fabrication, Appl. Phys. A. 116 (2014) 403-407. doi:10.1007/s00339-014-8468-2.

[39] S.P. Adusumilli, T.P. Dhakal, C.R. Westgate, Synthesis of Iron Pyrite Film through Low Temperature Atmospheric Pressure Chemical Vapor Deposition, MRS Online Proc. Libr. 1447 (2012) null-null. doi:10.1557/opl.2012.1461.

[40] T.P. Dhakal, Harve, Steve, van Hest, Maikel, G. Teeter, Back Contact Band Offset Study of Mo-CZTS Based Solar Cell Structure by Using XPS / UPS Techniques, Photovolt. Spec. Conf. (PVSC), 2015 IEEE 42nd. (2015) 1-4. doi:10.1109/PVSC.2015.7355623.

[41] D. Rudmann, D. Brémaud, H. Zogg, a. N. Tiwari, Na incorporation into $\mathrm{Cu}(\mathrm{In}, \mathrm{Ga}$ )Se[sub 2] for high-efficiency flexible solar cells on polymer foils, J. Appl. Phys. 97 (2005) 084903. doi:10.1063/1.1857059.

[42] Y. Li, Z. Han, L. Jiang, Z. Su, F. Liu, Y. Lai, Yexiang Liu, Template-directed synthesis of ordered iron pyrite (FeS2) nanowires and nanotubes arrays, J. Sol-Gel Sci. Technol. 72 (2014) 100-105. doi:10.1007/s10971-014-3425-2.

[43] T. Dhakal, D. Vanhart, R. Christian, A. Nandur, A. Sharma, C.R. Westgate, Growth morphology and electrical/optical properties of Al-doped $\mathrm{ZnO}$ thin films grown by atomic layer deposition, J. Vac. Sci. Technol. A. 30 (2012). doi:10.1116/1.3687939. 